\title{
PELUANG PENGEMBANGAN AGROINDUSTRI BERBASIS PERIKANAN LAUT DI DUSUN PAYANGAN DESA SUMBEREJO KECAMATAN AMBULU KABUPATEN JEMBER
}

\author{
Agroindustry Development Opportunities of Based Sea Fisheries in Sub Village of \\ Payangan Village of Sumberejo Sub District of Ambulu District of Jember
}

\author{
Oleh: \\ Syamsul Hadi ${ }^{*}$ dan Nurul Fathiyah Fauzi ${ }^{1}$ \\ 1 Program Studi Agribisnis Fakultas Pertanian Universitas Muhammadiyah Jember \\ *Korespondensi: syamsul.hadi@unmuhjember.ac.id
}

Diterima: 28 Maret 2016; Disetujui: 18 November 2016

\begin{abstract}
The development of agro-industries through the development of domestic industry based fisheries in the Payangan hamlet Sumberejo District of Ambulu Jember faced with various problems that started from the central issue is the level of knowledge and skills is relatively low, the ownership of venture capital is relatively limited, the production activities as individuals not groups, access difficult commercial lending and access to technology is also difficult. These conditions resulted in labor productivity and production quality is low. The purpose of this study were: 1) Knowing the agro-industry development opportunities based marine fisheries; 2) Analyze the added value of the fish catch if processed further; and 3) to analyze the socio-economic factors that affect the chances of developing agro-industries based marine fisheries. The method used is descriptive quantitative and qualitative survey techniques. Types of populations in this study were fishermen and craftsmen, artisans and fishermen of each sample taken as many as 10, 11 and 9 of the techniques of simple random sampling and quota sampling, while the data collection techniques used depth Interview. Analysis of the data used to answer the purpose of the first, second and third use analysis tools respective R/C Ratio, Value-added models Hayami and probability cumulative logit model. The results of this study concluded: 1) Opportunities-based agro-industrial development of marine fish in the study area is wide open $(R / C=4.61)$; 2) Activitybased agro-industry marine fish that includes pemindangan, fogging and making shrimp paste provide added value as much as Rp 43,672.02 per $\mathrm{kg}$ per production process; and 3) Simultaneously five independent variables significantly affect the chances of developing agroindustry and the partial factor significant business experience, whereas other estimators factors had no significant effect.
\end{abstract}

Keywords: added value, agro-industry, development opportunities

\section{ABSTRAK}

Pengembangan agroindustri melalui pengembangan industri rumah tangga yang berbasis perikanan di Dusun Payangan Desa Sumberejo Kecamatan Ambulu Kabupaten Jember dihadapkan pada berbagai masalah yang dimulai dari masalah pokok yaitu tingkat pengetahuan dan ketrrampilan relatif rendah, kepemilikan modal usaha relatif terbatas, kegiatan produksi secara perseorangan tidak berkelompok, akses pinjaman modal usaha sulit dan akses teknologi juga sulit. Kondisi ini mengakibatkan produktivitas tenaga kerja dan kualitas produksi menjadi rendah. Tujuan penelitian ini adalah: 1) Mengidentifikasi peluang pengembangan agroindustri berbasis perikanan 
laut; 2) Menganalisis nilai tambah hasil tangkapan dalam bentuk olahan; dan 3) Menganalisis faktor sosial ekonomi yang mempengaruhi peluang pengembangan agroindustri berbasis perikanan laut. Metode penelitian yang digunakan adalah deskriptif-kuantitatif dan kualitatif melalui teknik survei. Target responden adalah nelayan sekaligus pengrajin, pengrajin dan nelayan, sebanyak masing-masing 10,11 dan 9 orang melalui teknik simple random sampling dan quota sampling. Teknik pengumpulan data digunakan depth Interview. Analisis data yang digunakan untuk menjawab tujuan pertama, kedua dan ketiga digunakan alat analisis masing-masing $R / C$ Ratio, nilai tambah model Hayami dan probabilitas komulatif Model Logit. Adapun hasil penelitian ini menyimpulkan: 1) Peluang pengembangan agroindustri berbasis ikan laut di daerah penelitian sangat terbuka lebar $(R / C=4,61)$; 2) Kegiatan agroindustri berbasis ikan laut yang meliputi pemindangan, pengasapan dan pembuatan terasi memberikan nilai tambah sebanyak $\mathrm{Rp}$ 43.672,02 per kg per proses produksi; dan 3) Secara simultan kelima variabel bebas berpengaruh nyata terhadap peluang pengembangan agroindustri dan secara parsial faktor pengalaman berusaha berpengaruh nyata, sedangkan faktor penduga lainnya tidak berpengaruh nyata.

Kata kunci: nilai tambah, agroindustri, peluang pengembangan

\section{PENDAHULUAN}

Pantai selatan Jember khususnya di Dusun Payangan Desa Sumberejo Kecamatan Ambulu Kabupaten Jember memiliki luas perairan ZEE (Zone Ekonomi Eklusif) sebesar sekitar 200 mil laut yang di dalamnya terkandung potensi tangkap lestari sumberdaya hayati ikan yang mempunyai nilai ekonomis penting terlebih jika dikembangkan pada kegiatan agroindustri. Produk olahan seperti terasi ikan, kerupuk ikan tengiri, bakso ikan, ikan asap, tepung ikan dan lain-lain merupakan potensi pengembangan agroindustri yang dapat memberikan nilai tambah (added value). Harapannya adalah dapat memperluas kesempatan kerja dan meningkatkan pendapatan masyarakat pesisir yang sebagian besar masih hidup pada garis kemiskinan.

Walaupun potensi perikanan di kawasan pesisir tersebut mengandung ekspektasi yang luar biasa dalam pertumbuhan dan pergerakan perekonomian di Kabupaten Jember, namun masih banyak kendala yang dihadapi, yaitu antara lain: (1) kondisi pemasaran yang tidak mendorong perkembangan konsumsi, distribusi hasil produksi perikanan; (2) standar mutu atau kualitas ikan tangkapan dan sanitasi; (3) kondisi peralatan dan penerapan teknologi yang relatif rendah pada kegiatan penangkapan ikan di laut; (4) rasio jumlah modal dan tingkat biaya modal yang diperlukan masih sangat rendah; (5) Isu lingkungan merupakan persoalan yang banyak dikeluhkan dan dipakai sebagai alasan untuk menolak atau menahan pemasaran ikan; dan (6) kurang berkembangnya industri pengolahan hasil-hasil perikanan di daerah pesisir pantai (Soejono 2008). Salah satu pilihan alternatif pemecahan masalah adalah pengembangan agroindustri pengolahan hasil tangkapan yang dirancang untuk mendapatkan nilai tambah komersial yang maksimal dengan menghasilkan produk sesuai permintaan pasar.
Hal ini sesuai dengan hasil penelitian Huda et al. (2012) di Jawa Timur yang menyimpulkan bahwa pengolahan ikan mempunyai indeks daya penyebaran yang tinggi, keunggulan dalam pembentukan output, peningkatan pendapatan dan menciptakan lapangan kerja serta termasuk sub sektor yang berpotensi besar untuk dikembangkan di Jawa Timur.

Potensi pengembangan agroindustri melalui pengembangan industri rumah tangga yang berbasis perikanan di Dusun Payangan Desa Sumberejo Kecamatan Ambulu Kabupaten Jember dihadapkan pada berbagai masalah yang dimulai dari masalah pokok yaitu tingkat pengetahuan dan keterampilan relatif rendah, kepemilikan modal usaha relatif terbatas, kegiatan produksi secara perseorangan tidak berkelompok, akses pinjaman modal usaha sulit dan akses teknologi juga sulit. Kondisi yang demikian tersebut mengakibatkan produktivitas tenaga kerja dan kualitas produksi rendah karena motivasi kerja menjadi lemah. Pada gilirannya berimplikasi pada harga jual produk juga rendah. Berdasarkan fenomena di atas, maka yang menjadi tujuan dalam penelitian ini adalah mengidentifikasi peluang pengembangan agroindustri berbasis perikanan laut; menghitung nilai tambah produksi ikan tangkap jika diolah lebih lanjut; dan menentukan faktor-faktor sosial ekonomi yang mempengaruhi peluang pengembangan agroindustri berbasis perikanan laut.

\section{METODE}

Metode penelitian yang digunakan adalah metode survei, karena peneliti ingin melihat sejauh mana kondisi peluang pengembangan agroindustri berbasis ikan laut di daerah penelitian secara obyektif dan faktual, nilai tambah, dan faktor-faktor yang berpengaruh terhadap keputusan nelayan untuk melakukan kegiatan 
agroindustri terutama pada musim peceklik. Penelitian ini dilakukan pada Bulan JanuariMaret 2016, berlokasi di Dusun Payangan Desa Sumberejo Kecamatan Ambulu Kabupaten Jember secara purposive sampling atas pertimbangan bahwa di lokasi tersebut merupakan sentra penangkapan ikan laut dan terdapat kerajinan pengolahan ikan laut.

Populasi penelitian adalah nelayan, pengrajin agroindustri berbasis perikanan ikan laut dan nelayan sekaligus pengrajin yang masing-masing ditentukan secara acak sederhana dan sengaja melalui teknik quota sampling. Berdasarkan sumbernya, data yang dikumpulkan dalam penelitian ini meliputi data primer dan data sekunder. Data primer diperoleh dari ketiga jenis sampel yang dikumpulkan dengan Depth Interview yaitu wawancara langsung dengan responden yang mendalam dengan berpedoman pada daftar pertanyaan (kuisioner) terstruktur. Adapun data sekunder dikumpulkan dari instansi terkait dengan penelitian ini.

Pendekatan pengolahan data dalam penelitian ini dilakukan secara kuantitatif dan kualitatif. Pendekatan secara kuantitatif dilakukan karena jenis data yang dikumpulkan berskala ukuran interval dan rasio, sedangkan pendekatan kualitatif dilakukan karena jenis data yang dikumpulkan dalam penelitian ini juga berskala ukuran nominal dan ordinal. Proses pengolahan data ini memulai pekerjaan dengan melakukan editing dan coding dari hasil pengumpulan data. Selanjutnya dilakukan tabulasi yang berisi hubungan dari variabel yang banyak (multi-variable) secara mekanis (alat bantu komputer program exel versi 2010) untuk kemudian disajikan informasi berupa tabel frekuensi. Hasil pengolahan data ini selanjutnya diuji secara statistik melalui program aplikasi SPSS versi 16.

Guna menjawab tujuan pertama tentang identifikasi peluang pengembangan agroindustri di daerah penelitian, maka dilakukan dengan analisis Revenue Cost Ratio (R/C Rasio) untuk menghitung kelayakan ekonomi dengan kriteria sebagai berikut (Oktariza 2006 dalam Ngamel 2012): Jika nilai $\mathrm{R} / \mathrm{C}$ rasio $>1$ usaha dikatakan layak dan menguntungkan, Jika nilai $\mathrm{R} / \mathrm{C}$ rasio $<1$ usaha dikatakan tidak layak dan tidak menguntungkan, dan Jika nilai $\mathrm{R} / \mathrm{C}$ rasio $=1$ usaha dikatakan impas (tidak untung dan tidak rugi). Selanjutnya untuk menjawab tujuan kedua yaitu menghitung besarnya nilai tambah digunakan Metode Hayami dan Ruttan 1989 dalam Sudiyono 2001 dengan tiga indikator rasio nilai tambah yaitu (Hubeis 1997): 1) Jika besarnya rasio nilai tambah $<15 \%$, maka nilai tambahnya rendah; 2) Jika besarnya rasio nilai tambah 15\%-40\%, maka nilai tambahnya sedang; dan 3) Jika besarnya rasio nilai tambah $>40 \%$, maka nilai tambahnya tinggi. Adapun untuk menjawab tujuan ketiga tentang faktor sosial ekonomi yang berpengaruh terhadap peluang pengembangan agroindustri di daerah penelitian digunakan analisis probablititas komulatif model logit. Penggunaan model ini sesuai dengan model analisis yang digunakan oleh Lindawati (2007).

\section{HASIL DAN PEMBAHASAN}

\section{Peluang Pengembangan Agroindustri}

Peluang usaha penangkapan ikan di daerah penelitian relatif besar (Tabel 1). Hal ini dibuktikan dengan nilai $\mathrm{R} / \mathrm{C}$ rasio sebesar 1,76 dalam sekali melaut. Artinya tiap pengeluaran nelayan tiap $\mathrm{Rp} 1,-$ akan menghasilkan penerimaan sebesar $\mathrm{Rp} \mathrm{1,76,-.}$. Struktur biaya tertinggi terletak pada aspek biaya tenaga kerja dengan penggunaan rata-rata 3 orang tenaga kerja selama 9-12 jam kerja dan biaya tertinggi kedua dialokasikan untuk biaya bahan bakar minyak dengan penggunaan solar rata-rata 17,83 liter tiap melaut. Nilai R/C Ratio ini dalam kondisi normal musim ikan dan jika dalam kondisi tidak normal (musim peceklik) yaitu pada bulan Desember-Februari, maka nilai $\mathrm{R} / \mathrm{C}$ rationya menjadi lebih kecil. Bahkan pada saat penelitian ini dilakukan, terdapat 15,79\% nelayan yang memiliki nilai $\mathrm{R} / \mathrm{C}$ ratio di bawah nol dengan kata lain nelayan mengalami kerugian.

Sementera itu, hasil penelitian juga mengungkapkan bahwa peluang pengembangan agroindustri berbasis ikan laut di daerah penelitian sangat terbuka lebar. Hal ini dibuktikan dengan nilai $\mathrm{R} / \mathrm{C}$ ratio pada kegiatan agroindustri (pemindangan, pengasapan dan terasi) adalah sebesar 4,61 sebagaimana terlihat dalam Tabel 2. Artinya setiap pengeluaran biaya produksi sebesar Rp 1.,- akan memberikan tingkat penerimaan sebanyak Rp 4,61 per kg. Jika dibandingkan dengan nilai $\mathrm{R} / \mathrm{C}$ rasio dengan hanya menangkap ikan laut saja (Tabel 1), maka kegiatan agroindustri jauh lebih menguntungkan dengan perbandingan $1: 2,62$. Adapun nilai $\mathrm{R} / \mathrm{C}$ agroindustri di daerah penelitian lebih tinggi jika dibandingkan dengan hasil penelitian Soejono (2008) di Puger dimana nilai $\mathrm{R} / \mathrm{C}$ ratio pada kegiatan agroindustri terasi, kerupuk ikan, ikan kering, ikan pindang, dan tepung ikan masing-masing sebesar 1,82; 1,32; 1,31 dan 1,17.

Selanjutnya untuk lebih memberikan gambaran secara proporsional antara nilai $\mathrm{R} / \mathrm{C}$ ratio kegiatan agroindustri dengan menangkap 
Tabel 1 Hasil analisis $\mathrm{R} / \mathrm{C}$ ratio terhadap usaha penangkapan ikan laut oleh responden nelayan tiap melaut di daerah penelitian tahun 2016

\begin{tabular}{clrrrr}
\hline No & \multicolumn{1}{c}{ Uraian } & Satuan & Volume & Harga/Unit & \multicolumn{1}{c}{ Nilai (Rp) } \\
\hline A & Biaya Operasional : & & & & $\mathbf{2 9 1 . 7 3 0}$ \\
& 1. Sewa Alat Tangkap & Ls & 1 & 10.000 & 10.000 \\
& 2. Sewa Perahu/Penyusutan & Ls & 1 & 15.000 & 15.000 \\
& 3. Bahan Bakar Minyak & Liter & 17,83 & 6.000 & 106.980 \\
& 4. Tenaha Kerja & HOK & 3 & 42.500 & 127.500 \\
& 5. Konsumsi & Paket & 4,3 & 7.500 & 32.250 \\
B & Jumlah Hasil Tangkapan & Kg & $\mathbf{1 6 , 9 3}$ & & \\
C $\quad$ Harga Ikan Tangkap & Kg & & $\mathbf{3 0 . 2 8 5 , 7 1}$ & \\
D $\quad$ Total Revenue (TR) & & & & $\mathbf{5 1 2 . 7 3 7}$ \\
E $\quad$ Peluang (R/C) & & & & \\
\hline Sumber: Data Primer Diolah tahun 2016 & & & & $\mathbf{1 , 7 6}$ \\
\hline
\end{tabular}

Tabel 2 Hasil analisis R/C Ratio tentang peluang pengembangan agroindustri berbasis ikan laut tiap proses produksi di daerah penelitian tahun 2016

\begin{tabular}{clrrrr}
\hline No & \multicolumn{1}{c}{ Uraian } & Satuan & Volume & Harga/Unit & Nilai (Rp) \\
\hline A & Biaya Operasional : & & & & $\mathbf{8 5 1 . 2 4 1}$ \\
& 1. Penyusutan Alat & Ls & 1 & 7.500 & 7.500 \\
& 2. Bahan Baku & $\mathrm{Kg}$ & 56,25 & 11.588 & 651.838 \\
& 3. Bahan Penolong & $\mathrm{Ls}$ & 1 & 35.000 & 35.000 \\
& 4. Bahan Bakar & $\mathrm{Ls}$ & 1 & 3.667 & 3.667 \\
& 5. Tenaha Kerja & HOK & 3,76 & 38.690 & 145.476 \\
& 6. Kemasasan & Unit & 38,8 & 200 & 7.760 \\
B & Jumlah Hasil Produksi & $\mathrm{Kg}$ & $\mathbf{6 4 , 2 9}$ & & \\
C & Harga Produksi Olahan & $\mathrm{Kg}$ & & $\mathbf{6 1 . 0 2 4}$ & \\
D $\quad$ Total Revenue (TR) & & & & $\mathbf{3 . 9 2 2 . 9 5 9}$ \\
E & Peluang (R/C) & & & & \\
\hline Sumber: Data Primer Diolah tahun 2016 & & & &
\end{tabular}

Sumber: Data Primer Diolah tahun 2016

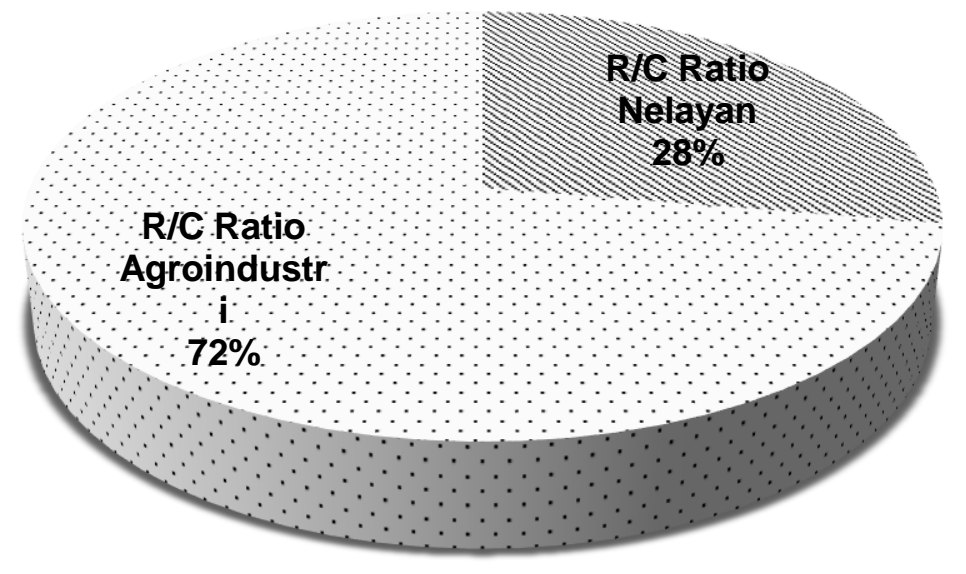

Gambar 1 Perbandingan nilai $\mathrm{R} / \mathrm{C}$ ratio antara hasil kegiatan agroindustri dengan kegiatan menangkap ikan di Dusun Payangan-Watuolo Desa Sumberejo Kecamatan Ambulu Kabupaten Jember tahun 2016 (Sumber: Data Primer Diolah Tahun 2016) 
ikan saja, dapat dilihat pada Gambar 1. Hasil penelitian ini juga mengungkapkan bahwa kelompok responden yang bertindak sebagai nelayan sekaligus pengrajin memiliki rata-rata nilai $\mathrm{R} / \mathrm{C}$ rasio pada kegiatan kerajinannya mencapai 3,84, sedangkan untuk kelompok responden yang hanya bertindak sebagai pengrajin saja rata-rata nilai $\mathrm{R} / \mathrm{C}$ rasionya mencapai 5,31. Kondisi ini disebabkan intensifikasi usaha agroindustri pada kelompok responden pertama kurang berjalan maksimal karena konsentrasi manajemennya terpecah pada kegiatan menangkap ikan. Sedangkan pada kelompok responden kedua, lebih terkonsentrasi pada pengelolaan satu kegiatan. Kondisi peluang pengembangan agroindustri di daerah penelitian sejalan dengan hasil Hastinawati dan Rum (2012) bahwa secara finansial agroindustri kerupuk udang di Desa Kwanyar Barat Kecamatan Kwanyar Kabupaten Bangkalan dinilai layak untuk dilaksanakan karena diperoleh nilai $\mathrm{R} / \mathrm{C}$ Ratio sebesar 1,43 . Selain itu, besarnya peluang pengembangan agroindustri perikanan laut di daerah penelitian ini sesuai dengan hasil penelitian Fatih (2010) bahwa pengembangan agroindustri perikanan laut di Kecamatan Tambak Boyo Kabupaten Tuban adalah positif, dimana faktor pendorong lebih dominan dibanding dengan faktor penghambat, dimana faktor pendorong dimaksud antara lain: kekayaan komoditas laut melimpah dan beragam, pengolahan mudah, peluang ekspor, dan permintaan pasar cukup luas baik domestik maupun ekspor. Namun demikian di sisi lain hasil penelitian Zulkarnain et al. (2013) mengungkapkan bahwa semakin tingginya nilai tambah yang diperoleh para pelaku usaha agroindustri, memicu persaingan yang makin meningkat baik dalam memperoleh bahan baku maupun dalam pemasaran produk hasil olahan.

\section{Nilai Tambah Agroindustri lkan Laut}

\section{Output, input, dan harga}

Hasil analisis nilai tambah dengan menggunakan model Hayami dan Ruttan (1989) sebagaimana pada Tabel 3 mengungkapkan bahwa dari kegiatan agroindustri berbasis ikan laut yang meliputi: pemindangan, pengasapan dan pembuatan terasi memberikan nilai tambah sebanyak Rp 43.672,02 per kg per proses produksi. Besarnya nilai tambah tergantung pada biaya yang dikeluarkan meliputi rata-rata biaya pembelian bahan baku sebesar Rp 10.952,38 per $\mathrm{kg}$ yang berkisar antara $\mathrm{Rp} 7.000 \mathrm{s.d} \mathrm{Rp}$ 40.000,- per $\mathrm{kg}$ dan sumbangan input lain sebesar Rp 8.119,05 per unit. Sumbangan input lain terdiri dari seluruh biaya variabel kecuali biaya bahan baku dan upah tenaga kerja. Input lain di dalamnya mencakup biaya pembelian bahan penolong (bumbu, garam, dan zat aditif), bahan bakar, kemasan, dan penyusutan alat. Besarnya nilai tambah agroindustri hasil penelitian ini lebih tinggi daripada nilai tambah agroindustri atas hasil penelitian Purwaningsih (2015) di Muncar Banyuwangi dimana kegiatan agroindustri pengalengan ikan, cold storage, tepung ikan dan minyak ikan memiliki rasio nilai kurang dari $40 \%$. Adapun rasio nilai tambah dari proses pengolahan produk berbasis ikan laut di daerah penelitian mencapai $69,60 \%$ dan tergolong rasio tinggi (> $40 \%)$.

Tenaga kerja adalah jumlah orang yang dibutuhkan dalam proses produksi, dimana satu HOK adalah delapan jam kerja atau satu hari kerja orang dewasa. Besarnya nilai koefisien tenaga kerja menunjukkan besarnya sumbangan tenaga kerja yang dibutuhkan untuk mengolah satu kilogram bahan baku ikan laut. Tabel 3 di bawah menggambarkan bahwa ratarata alokasi tenaga kerja sebanyak $6,14 \mathrm{HOK}$ terhadap penggunaan input bahan baku sebanyak $62,52 \mathrm{~kg}$ per proses produksi diperoleh imbalan tenaga kerja sebesar Rp 3.801,27 / kg dari upah rata-rata tenaga kerja sebesar $\mathrm{Rp}$ $38.690,48$ /HOK tiap proses produksi.

Sementara itu, nilai faktor konversi yaitu perbandingan antara output dengan input, dimana dalam penelitian ini rata-rata nilai konversinya sebesar 1,03 dan rata-rata nilai koefisien tenaga kerja sebesar 0,10. Atas dasar rata-rata nilai konversi dan koefisien tenaga kerja tersebut dapat diartikan bahwa untuk mengolah $100 \mathrm{~kg}$ bahan baku ikan laut menjadi $103 \mathrm{~kg}$ produk olahan diperlukan tenaga kerja langsung sebanyak $100 \mathrm{HOK}$. Besarnya nilai koefisien tenaga kerja dapat dilihat apakah pengusaha sudah efisien melakukan proses produksi atau belum. Semakin kecil nilai koefisien tenaga kerja maka semakin efisien pengusaha berproduksi. Dalam konteks ini penggunaan tenaga kerja sebanyak 6,14 HOK untuk mengolah bahan baku ikan laut sebanyak 62,52 $\mathrm{kg}$ untuk menghasilkan produksi olahan sebanyak $64,29 \mathrm{~kg}$ sangat tidak efisien.

\section{Pendapatan dan keuntungan}

Besarnya pendapatan atau imbalan yang diterima oleh tenaga kerja diperoleh dari hasil kali antara koefisien tenaga kerja dengan ratarata upah tenaga kerja. Besarnya rata-rata upah tenaga kerja per proses produksi yaitu $\mathrm{Rp}$ $38.690,48$ per orang. Besarnya upah tersebut diperoleh dari upah riil yang diterima oleh tenaga kerja secara keseluruhan pada masingmasing proses produksi. Jadi besarnya pendapatan yang diterima oleh tenaga kerja langsung dari pengolahan ikan laut adalah $\mathrm{Rp}$ 
$3.801,27$ per $\mathrm{kg}$ dengan bagian tenaga kerja sebesar $8,70 \%$ dari nilai tambah.

Pada Tabel 3 juga mengungkapkan bahwa rata-rata keuntungan perusahaan yang diperoleh dari kegiatan agroindustri yaitu sebesar Rp 39.870,74 per $\mathrm{kg}$ atau tingkat keuntungan sebesar $91,30 \%$ dari nilai tambah produk yang berarti setiap satu $\mathrm{kg}$ produk olahan ikan laut yang dihasilkan mampu memberikan keuntungan sebesar Rp 39.870,74. Hasil penelitian Pertiwi et al. (2015) bahwa harga jual yang diterima, merupakan nilai tambah hasil kegiatan agroindustri berbasis ikan laut seperti bakso, ekado dan lumpia adalah $\mathrm{Rp} 8.000$ dan Rp 10.000, sedangkan harga jual otak-otak dan filetan masing-masing adalah $\mathrm{Rp} 50.000$ dan Rp 30.000 untuk setiap bungkusnya. Hasil penelitian ini juga sejalan dengan hasil penelitian Ngamel (2012) tentang peningkatan nilai tambah rumput laut yang diolah menjadi tepung karaginan yang merupakan hasil ekstraksi dari rumput laut sebesar Rp 9.362,50. Artinya pengolahan rumput laut menjadi tepung karaginan adalah memberikan nilai tambah positif bagi sumberdaya laut. Adapun keuntungan yang diperoleh dari proses pengolahan ikan menjadi produk bakso adalah $\mathrm{Rp}$ $7.760,42$, ekado $R p$ 45.572,92, lumpia $R p$ 48.697,92, serta otak-otak Rp 21.256,67 dan piletan $\mathrm{Rp} 4.771,92$ per $\mathrm{kg}$.

\section{Balas jasa untuk faktor produksi}

Balas jasa faktor produksi terdiri atas balas jasa untuk faktor produksi tenaga kerja, input lain, dan tingkat keuntungan. Marjin merupakan selisih harga atau nilai produk dengan nilai input bahan bakunya yang digunakan. Marjin akan didistribusikan untuk imbalan tenaga kerja, sumbangan input lain, dan keuntungan perusahaan atau pengrajin. Rata-rata margin dari produksi olahan adalah sebesar $\mathrm{Rp}$ $51.791,06$ per $\mathrm{kg}$ bahan baku ikan laut yang terdiri atas $7,34 \%$ pendapatan tenaga kerja, $15,68 \%$ sumbangan input lain, dan $76,98 \%$ keuntungan pengrajin. Marjin keuntungan perusahaan merupakan marjin yang terbesar dan jauh lebih besar dibandingkan dengan marjin pendapatan tenaga kerja. Hal tersebut menunjukkan bahwa usaha pengolahan ikan laut menjadi produk olahan terutama terasi merupakan usaha padat modal, sedangkan pengolahan pemindangan dan pengasapan ikan laut lebih cenderung padat karya.

\section{Faktor Sosial Ekonomi yang Mempenga- ruhi terhadap Peluang Pengembangan Agroindustri}

Beberapa faktor yang diduga mempengaruhi keputusan nelayan dalam melakukan pengolahan diantaranya: 1) modal yang dikuasai nelayan (Rp) $\left(X_{1}\right)$, 2) pengalaman berusaha baik sebagai nelayan atau pengrajin (tahun) $\left.\left(X_{2}\right), 3\right)$ perhatian/dukungan pemerintah $\left.\left(X_{3}\right), 4\right)$ ketersediaan bahan baku $\left(\mathrm{X}_{4}\right)$, dan 5) peluang pemasaran produk olahan $\left(X_{5}\right)$. Kelima faktor yang diduga mempengaruhi nelayan dalam pengambilan keputusan melakukan pengolahan, diuji dengan menggunakan pendekatan Analisis Probabilitas Komulatif Logit Model (Gujarati 1995). Y diinput dengan menggunakan kode kategori yang dinyatakan dengan angka 0 dan 1. Angka 0 disebut sebagai excluded group untuk nelayan yang tidak melakukan proses pengolahan ikan dan angka 1 disebut included group yang digunakan sebagai kode untuk nelayan yang melakukan pengolahan yang diuji pada taraf kepercayaan $90 \%$ atau dengan nilai $\alpha=10 \%$

Hasil analisis mengenai faktor-faktor yang mempengaruhi keputusan nelayan untuk melakukan pengolahan ikan berdasarkan analisis logit yakni tabel Omnibus Test of Model Coefficients dapat digunakan untuk menilai apakah model yang akan dimasukkan sudah sesuai dengan data, mengacu hasil pada 3 langkah yakni Step, Block, dan Model. Dengan kata lain, hasil Omnibus Test of Model Coeff ini dapat digunakan untuk melihat hasil pengujian secara simultan pengaruh dari kelima variabel bebas berdasarkan nilai Signifikansi. Hasil Omnibus Test of Model Coefficients disajikan pada Tabel 4.

Berdasarkan Tabel 4 dapat diketahui bahwa nilai signifikansinya dari ketiga langkah tersebut sebesar 0,071 . Nilai signifikan hasil analisis lebih kecil dari nilai $0,10(0,071<0,10)$ sehingga diartikan bahwa secara simultan kelima variabel bebas yang diteliti berpengaruh secara signifikan terhadap pengambilan keputusan nelayan dalam melakukan pengolahan ikan sehingga dapat dilanjutkan ketahap analisis selanjutnya. Uji Cox and Snell's Square dan Nagelkerke's $R$ Square dilakukan untuk melihat seberapa besar model yang digunakan dalam penelitian ini mampu menjelaskan variabel dependen dengan menggunakan variabel-variabel independen yang digunakan dalam penelitian ini. Nilai Cox \& Snell $R$ Square merupakan ukuran yang mencoba meniru ukuran $\mathrm{R}^{2}$ pada multiple regression yang didasarkan pada teknik estimasi likelihood dengan nilai maksimum kurang dari 1, sedangkan untuk nilai Nagelkerke $R$ Square dapat disamakan dengan nilai Adjusted $R^{2}$ pada multiple regression. Hasil analisis tersebut menunjukkan bahwa nilai Nagelkerke $R$ Square sebesar 0,407 artinya sebesar $40,7 \%$ keputusan nelayan untuk melakukan pengolahan ikan dipengaruhi oleh kelima faktor yang telah ditentukan dalam 
penelitian ini. Atau dapat pula dikatakan bahwa sebesar $40,7 \%$ variabel $\mathrm{Y}$ dipengaruhi oleh $\mathrm{X}_{1}-$ $\mathrm{X}_{5}$, sedangkan sisanya sebesar $59,3 \%$ dipengaruhi oleh variabel lain di luar model persamaan yang telah ditentukan oleh peneliti.

Uji Hosmer and Lemeshow Goodness of Fit Test dilakukan dengan menguji hipotesis nol untuk mendapatkan bukti bahwa data empiris yang digunakan cocok atau sesuai dengan model. Mengacu pada Ghozali (2009), apabila nilai Hosmer and Lemeshow signifikan $(<0,10)$, maka hipotesis nol ditolak dan model dianggap tidak sesuai karena ada perbedaan signifikan antara model dengan data yang diobservasi. Apabila nilai Hosmer and Lemeshow lebih besar dari 0,10 , maka hipotesis nol diterima (Non signifikan). Hasil analisis menunjukkan bahwa nilai signifikansinya sebesar 0,162 yang berarti model regresi logistik layak digunakan untuk analisa selanjutnya karena tidak ada perbedaan signifikan antara model dengan data yang diobservasi. Classification Table digunakan untuk memprediksi nilai estimasi yang benar (correct) dan yang salah (incorrect). Prediksi dari nilai estimasi yang benar ditunjukkan dari nilai diagonal yang miring ke kiri, yaitu dengan nilai 5 pada nelayan yang tidak mengolah dan 21 pada nelayan yang melakukan pengolahan. Untuk prediksi yang salah ditunjukkan dari nilai diagonal yang miring ke kanan, yaitu masingmasing sebesar 4 dan 0 nilai prediksi.

Persentase ketepatan keseluruhan model (Overall Percentage) sebesar 86,7\%, nilai ini mendekati $100 \%$. Oleh karena itu model dapat diterima dan dilanjutkan dengan analisis selanjutnya yaitu pengujian dari pengaruh masing-masing variabel bebas terhadap keputusan nelayan. Hasil pengujian kesesuaian model logit, menunjukkan bahwa pengujian regresi logistik secara parsial dapat dilakukan dengan melihat tabel Variables in the Equation. Tabel tersebut dapat pula ditentukan bentuk model persamaan regresi logit dari pengambilan keputusan nelayan melakukan pengolahan serta mengetahui nilai signifikansi dan Odds Ratio (Exp. B), dimana hasil analisisnya dapat dilihat pada Tabel 5.

Berdasarkan hasil analisis logit diperoleh bentuk persamaan umum pengambilan keputusan nelayan $(\mathrm{Y})$ yakni:

$Y=-4,564+0,000 X_{1}-0,105 X_{2}+0,5 X_{3}+0,901 X_{4}+$ $1,015 X_{5}$
$(0,652) \quad(0,100)^{*}$
$(0,487)$
$(0,296)$
$(0,204)$

Bentuk rumusan Logit Model dari persamaan umum di atas yakni:

$\mathrm{Pi}=\mathrm{E}(\mathrm{Y}=1 / \mathrm{Xi})=\frac{1}{1+\mathrm{e}^{-(-4,564+0,000 \times 1-0,105 \times 2+0,5 \times 3+0,901 \times 4+1,015 \times 5)}}$

Tabel 3 Hasil analisis nilai tambah agroindustri berbasis ikan laut Dusun Payangan-Watuolo Desa Sumberejo Kecamatan Ambulu Kabupaten Jember tahun 2016

\begin{tabular}{|c|c|c|}
\hline & Output, Input, Harga*) & Formula*) \\
\hline 1 & Hasil produksi (kg/proses produksi) & 64,29 \\
\hline 2 & Bahan baku (kg /proses produksi) & 62,52 \\
\hline 3 & Tenaga kerja (HOK) /proses produksi & 6,14 \\
\hline 4 & Faktor konversi (1 / 2) & 1,03 \\
\hline 5 & Koefisien tenaga kerja (3 / 2) & 0,10 \\
\hline 6 & Harga produk (Rp / Kg) & $61.023,81$ \\
\hline 7 & Upah rerata (Rp / HOK) & $38.690,48$ \\
\hline \multicolumn{3}{|c|}{ Pendapatan dan Keuntungan } \\
\hline 8 & Harga bahan baku (Rp / kg) & $10.952,38$ \\
\hline 9 & Sumbangan input lain/bahan penolong dll. (Rp / kg) & $8.119,05$ \\
\hline 10 & Nilai produk (4x6) (Rp / kg) & $62.743,44$ \\
\hline 11 & a. Nilai tambah $(10-9-8)(\mathrm{Rp} / \mathrm{kg})$ & $43.672,02$ \\
\hline 17 & b. Rasio nilai tambah (11.a / 10) x $100(\%)$ & 69,60 \\
\hline 12 & a. Imbalan Tenaga kerja (5x7) (Rp / kg) & $3.801,27$ \\
\hline 12 & b. Bagian tenaga kerja (12.a. / 11.a.) x 100 (\%) & 8,70 \\
\hline 13 & a. Keuntungan $(11 \mathrm{a}-12 \mathrm{a})$ per $\mathrm{Kg}$ & $39.870,74$ \\
\hline 13 & b. Tingkat keuntungan (13.a / 11.a) x $100(\%)$ & 91,30 \\
\hline \multicolumn{3}{|c|}{ Balas Jasa Untuk Faktor Produksi } \\
\hline 14 & Margin $(\mathrm{Rp} / \mathrm{kg})=(10-8)$ & $51.791,06$ \\
\hline 15 & Pendapatan tenaga kerja langsung $(12 a / 14) \times 100 \%$ & 7,34 \\
\hline 16 & Sumbangan input lain $(9 / 14) \times 100 \%$ & 15,68 \\
\hline 17 & Keuntungan perusahaan (13a /14)x 100\% & 76,98 \\
\hline
\end{tabular}


Tabel 4 Tabel Omnibus Test of Model Coefficients

\begin{tabular}{lcccc}
\hline & & Chi-square & df & Sig. \\
\hline \multirow{3}{*}{ Step 1 } & Step & 10,152 & 5 &, 071 \\
& Block & 10,152 & 5 &, 071 \\
& Model & 10,152 & 5 &, 071 \\
\hline
\end{tabular}

Sumber: Data Primer Diolah Tahun 2016

Tabel 5 Hasil analisis regresi logistik faktor-faktor pengambilan keputusan nelayan melakukan pengolahan ikan

\begin{tabular}{|c|c|c|c|c|c|c|c|c|c|}
\hline \multirow{2}{*}{\multicolumn{2}{|c|}{ Model }} & \multirow{2}{*}{ B } & \multirow{2}{*}{ S.E. } & \multirow{2}{*}{ Wald } & \multirow{2}{*}{ Df } & \multirow{2}{*}{ Sig. } & \multirow{2}{*}{$\operatorname{Exp}(B)$} & \multicolumn{2}{|c|}{ 90\% C.I.for EXP(B) } \\
\hline & & & & & & & & Lower & Upper \\
\hline \multirow[t]{6}{*}{ Step $1^{a}$} & $X_{1}$ & ,001 & ,001 & ,204 & 1 & ,652 & 1,000 & 1,000 & 1,000 \\
\hline & $X_{2}$ &,- 105 & ,079 & 1,769 & &, $100^{*}$ & 900 & ,790 & 1,025 \\
\hline & $X_{3}$ &, 500 & ,718 & ,484 & 1 & ,487 & 1,649 &, 506 & 5,374 \\
\hline & $\mathrm{X}_{4}$ & ,901 & ,863 & 1,091 & 1 & ,296 & 2,463 & ,596 & 10,180 \\
\hline & $X_{5}$ & 1,015 & ,798 & 1,615 & 1 & ,204 & 2,758 & ,742 & 10,255 \\
\hline & Constant & $-4,564$ & 4,952 & 849 & 1 & ,357 & ,010 & & \\
\hline
\end{tabular}

a. Variable(s) entered on step 1: $X_{1}, X_{2}, X_{3}, X_{4}, X_{5}$.

Keterangan: *) Signifikan pada $\alpha=10 \%$

Nilai B dari Tabel 5 menunjukkan besarnya nilai konstanta dan koefisien regresi pada msing-masing variabel bebas. Nilai S.E merupakan nilai standart error dari masing-masing variabel bebas. Nilai Wald dapat disamakan dengan nilai Chi-square. Nilai tersebut diperoleh dari hasil perbandingan antara nilai $B$ dengan standart error yang kemudian dikuadratkan. Uji Wald ini dapat digunakan untuk menguji signifikansi tiap parameter dengan membandingkan hasil Wald dengan nilai Chisquare pada $\mathrm{df}=1$. Nilai Chi-square $(0,10 ; 1)$ yakni sebesar 2,706. Jika nilai Wald >2,706 maka variabel bebas berpengaruh nyata terhadap pengambilan keputusan nelayan untuk mengolah ikan. Signifikansi masing-masing variabel bebas dapat pula dilihat secara langsung dari nilai Sig. dengan taraf kepercayaan $90 \%$. Jika Sig $\leq 0,10$ maka variabel bebas tersebut berpengaruh nyata terhadap keputusan nelayan mengolah ikan. Untuk nilai $\operatorname{Exp~(B)~}$ merupakan nilai Odds Ratio yang merupakan ukuran kecenderungan atau probabilitas untuk nelayan melakukan pengolahan ikan. Model persamaan $\mathrm{Y}$ dan hasil analisis uji parsial berdasarkan Tabel 5 dapat diinterpretasikan lebih lanjut sebagai berikut:

\section{Variabel modal $\left(\mathbf{X}_{1}\right)$}

Besarnya modal menjadi salah satu faktor yang diduga berpengaruh terhadap pengambilan keputusan nelayan untuk melakukan pengolahan lebih lanjut terhadap ikan. Hasil analisis menunjukkan bahwa nilai Uji Wald variabel ini sebesar 0,204 yang berarti nilai tersebut lebih kecil dari Chi-square $(0,10 ; 1) 2,706$ $(0,204<2,706)$. Sehingga dapat dikatakan bahwa variabel bebas $X_{1}$ tidak berpengaruh nyata terhadap pengambilan keputusan nelayan melakukan pengolahan ikan. Nilai Signifikansi dapat pula dilihat bahwa signifikansi $X_{1}$ sebesar 0,652 lebih besar jika dibandingkan $0,10(0,652>0,10)$ sehingga variabel $X_{1}$ ini tidak berpengaruh nyata dalam pengambilan keputusan nelayan.

Nilai koefisien regresi $X_{1}$ sebesar 0,001 yang menunjukkan tidak ada pengaruh dari besarnya modal terhadap keputusan nelayan melakukan pengolahan ikan dengan asumsi variabel lain dianggap konstan. Adapun nilai Odds Ratio sebesar 1,000 menunjukkan bahwa peluang nelayan melakukan pengolahan ikan dengan variabel $X_{1}$ sebesar 1 kali lebih rendah dibanding dengan nelayan yang tidak melakukan pengolahan ikan. Apabila modal usaha bertambah belum tentu nelayan akan melakukan kegiatan pengolahan ikan, terlebih modal usaha yang dimiliki terbatas atau bahkan terjerat pada kekuatan rentenir (pengambek).

Hasil penelitian ini sejalan dengan hasil penelitian Lindawati (2007) yang dilakukan di Kecamatan Medan Belawan dengan kesimpulan bahwa faktor Dummy Bantuan Modal (DBM) berpengaruh tidak nyata terhadap peluang istri nelayan untuk bekerja mengolah ikan. Hal ini karena pendapatan suami sebagai nelayan tidak cukup untuk memenuhi kebutuhan keluar- 
ganya yang layak akibat tidak dapat melaut sepanjang tahun, yaitu pada musim angin barat (Bulan November-Mei) dan juga setiap hari Jumat. Oleh karena itu, ada atau tidak ada bantuan modal, istri nelayan tetap melakukan kegiatan mengolah ikan untuk menopang ekonomi keluarganya agar dapat hidup lebih layak.

\section{Variabel pengalaman berusaha $\left(X_{2}\right)$}

Pengalaman memiliki nilai kofisien -0,105 yang dapat dikatakan bahwa semakin meningkat pengalaman nelayan (tahun), maka akan semakin menurunkan probabilitas keputusan nelayan untuk melakukan pengolahan sebesar 0,105 kali dengan asumsi kondisi variabel lain konstan. Nilai Exp (B) menunjukkan angka sebesar 0,90. Hal ini berarti bahwa semakin lama pengalaman nelayan sebesar 1 tahun, maka akan menyebabkan resiko pengambilan keputusan nelayan mengolah lebih lanjut akan semakin rendah sebesar 0,90 kali. Hal ini disebabkan sejatinya nelayan tidak mau ambil resiko untuk melakukan transformasi pekerjaan dengan melakukan deversifikasi usaha pengolahan ikan laut meskipun mampu menyiapkan bahan baku sendiri. Nilai Uji Wald dan nilai signifikansi menunjukkan bahwa variabel pengalaman secara nyata berpengaruh terhadap keputusan nelayan untuk mengolah.

\section{Variabel dukungan pemerintah $\left(X_{3}\right)$}

Variabel bebas $X_{3}$ memiliki nilai koefisien regresi sebesar 0,50 yang menunjukkan bahwa semakin bertambah dukungan pemerintah terhadap agroindustri pengolahan ikan di Payangan, maka akan semakin tinggi keputusan nelayan untuk melakukan pengolahan ikan sebesar 0,50 kali dengan asumsi kondisi variabel lain tetap. Nilai Exp (B) atau Odds Ratio menunjukkan angka sebesar 1,649. Hal ini berarti bahwa semakin tinggi faktor dukungan pemerintah maka akan menyebabkan kecenderungan pengambilan keputusan nelayan mengolah ikan lebih tinggi sebesar 1,649 kali dari pada nelayan yang tidak melakukan pengolahan. Nilai Uji Wald dan signifikansi menunjukkan bahwa variabel meminimalkan atau menghindari resiko ini tidak berpengaruh secara nyata terhadap keputusan nelayan untuk melakukan pengolahan lebih lanjut pada taraf kepercayaan $90 \%$ dengan nilai signifikansi sebesar 0,487 atau $\left.\beta_{3}>0,10\right)$.

\section{Variabel ketersediaan bahan baku $\left(\mathrm{X}_{4}\right)$}

Variabel ketersediaan bahan baku dalam penelitian ini menunjukkan bahwa nilai koefisien regresi terhadap pengambilan keputusan nelayan menebaskan sebesar 0,901. Hubungan positif ini dapat diartikan bahwa apabila ketersediaan bahan baku bertambah 1 satuan maka akan meningkatkan kecenderungan nelayan untuk melakukan pengolahan ikan sebesar 0,901 kali dengan asumsi variabel lain yang dalam keadaan konstan. Nilai Exp (B) variabel usia sebesar 2,463 yang dapat diartikan bahwa nelayan yang memiliki ketersediaan bahan baku lebih tinggi 1 satuan maka akan memiliki peluang mengolah ikan sebesar 2,463 kali dibandingkan nelayan yang tidak mengolah, jika kondisi variabel atau faktor lain dianggap tetap. Jika dilihat dari nilai Uji Wald dan signifikansi menunjukkan bahwa variabel $X_{4}$ tidak memberikan pengaruh nyata terhadap keputusan nelayan melakukan pengolahan (yakni 2,96 $>0,10)$. Sehingga dari nilai tersebut diartikan bahwa variabel ketersediaan bahan baku tidak mempunyai pengaruh nyata dalam pengambilan keputusan nelayan untuk melakukan proses pengolahan ikan lebih lanjut. Hasil penelitian ini tidak sejalan dengan hasil penelitian Oktaviani dan Sardjito (2012) di Kabupaten Tuban bahwa faktor bahan baku menjadi faktor penentu nyata untuk pengembangan industri berbasis perikanan laut.

\section{Variabel Peluang Pemasaran $\left(\mathbf{X}_{5}\right)$}

Variabel pemasaran memiiki nilai koefisien regresi sebesar 1,015 yang dapat dikatakan bahwa apabila faktor pemasaran semakin meningkat sebesar 1,015 maka akan meningkatkan kecenderungan nelayan untuk melakukan pengolahan ikan 1,015 kali dengan kondisi variabel lain dalam keadaan konstan. Nilai Exp (B) sebesar 2,758 yang dapat diartikan bahwa nelayan dengan tingkat pemasaran ikan olahan yang lebih tinggi akan memiliki peluang melakukan pengolahan ikan sebesar 1 kali dibandingkan nelayan lain, jika kondisi variabel atau faktor lain dianggap konstan. Nilai signifikansi sebesar 0,204 akan tidak berpengaruh nyata terhadap pengambilan keputusan nelayan melakukan pengolahan ikan pada $\alpha=0,10$. Hasil Predicted Probabilities atau Class Plot dapat digunakan untuk menilai ketepatan prediksi regresi logistic dengan disesuaikan pada kondisi yang sebenarnya. Dengan kata lain, Predicted Probabilities ini dapat digunakan sebagai prediksi peluang keputusan nelayan melakukan pengolahan ikan dan tidak mengolah ikan pada kondisi lapang. Sumbu X merupakan probabilitas prediksi dari 0 hingga 1, sedangkan sumbu $\mathrm{Y}$ merupakan frekuensi jumlah kasus yang dikelompokkan berdasarkan nelayan yang melakukan pengolahan ikan $(\mathrm{m})$ dan yang tidak mengolah ikan (t).

Class Plot dapat dijelaskan dari hasil analisis probabilitas komulatif tersebut bahwa predicted probability group dilakukan pada ska- 
la 0 hingga 1 dengan melihat jumlah frekuensi nelayan yang melakukan pengolahan dan yang tidak melakukan pengolahan pada rentang prediksi 0,1 . Pada prediksi probabilitas 0 hingga 0,3, nampak bahwa frekuensi yang ada yakni nelayan yang tidak melakukan pengolahan (t) dan tidak muncul frekuensi nelayan yang melakukan pengolahan $(m)$. Semakin mendekati angka 1, frekuensi nelayan yang akan melakukan pengolahan $(\mathrm{m})$ semakin meningkat dan frekuensi $(\mathrm{t})$ semakin menurun.

\section{KESIMPULAN}

Peluang pengembangan agroindustri berbasis ikan laut di daerah penelitian sangat terbuka lebar, hal ini didukung oleh hasil analisis efisiensi biaya melalui alat analisa $R / C$ ratio bahwa agroindustri (pemindangan, pengasapan dan terasi) adalah sebesar 4,61. Kegiatan agroindustri berbasis ikan laut di daerah penelitian yang meliputi: pemindangan, pengasapan dan pembuatan terasi memberikan nilai tambah sebanyak Rp 43.672,02 per kg per proses produksi dan rasio nilai tambah dari proses pengolahan produk berbasis ikan laut mencapai $69,60 \%$ dan tergolong rasio tinggi karena nilainya $>40 \%$. Secara simultan kelima variabel bebas yang diteliti berpengaruh secara signifikan terhadap pengambilan keputusan nelayan dalam melakukan kegiatan agroindustri pada taraf nyata $10 \%$. Namun secara parsial diperoleh fakta bahwa hanya variabel pengalaman berusaha berpengaruh nyata terhadap peluang pengembangan agroindustri, sedangkan variabel modal yang dikuasai nelayan, perhatian/dukungan pemerintah, ketersediaan bahan baku dan peluang pemasaran produk olahan berpengaruh tidak nyata.

\section{SARAN}

Bagi nelayan yang belum mencoba melakukan deversifikasi usaha melalui kegiatan agroindustri, hendaknya mencoba untuk melakukannya karena memiliki nilai tambah yang cukup tinggi sejalan dengan peluang pasarnya yang cukup luas. Bagi pengrajin yang sedang menjalani usaha agroindustri khususnya pemindangan dan pengasapan, hendaknya mengurangi alokasi tenaga kerja karena imbalan tenaga kerja atas nilai tambah terlalu tinggi dan bila memungkinkan perlu ada penambahan modal. Bagi stakesholders terkait seperti lembaga keuangan, perguruan tinggi dan lembaga supporting lainnya hendaknya melakukan kemitraan dengan pelaku agroindustri agar peluang pengembangan agroindustri di daerah penelitian semakin luas.

\section{UCAPAN TERIMA KASIH}

Ucapan terima kasih disampaikan penulis kepada Lembaga Penelitian dan Pengabdian pada Masyarakat (LPPM) Universitas Muhammadiyah Jember atas dukungan dana penelitian internal pada tahun anggaran 2015-2016, sehingga penulis dapat mempublikasikan hasil penelitian ini pada jurnal nasional terakreditasi “ Jurnal Marine Fisheries-IPB".

\section{DAFTAR PUSTAKA}

Fatih C. 2010. Strategi Pengembangan Agroindustri Perikanan Laut di Kabupaten Tuban. Jurnal Sosial Ekonomi Pertanian. 4(3): 77-88.

Ghozali I. 2009. Validitas dan Reliabilitas Data dalam Penelitian. Jakarta: Ghalia Indonesia.

Gujarati D. 1995. Ekonometrika Dasar. Bernard Baruch College City Univericity of New York. Dialih bahasakan oleh Sumarno Zain. Universitas Padjadjaran Bandung. Jakarta: Penerbit Erlangga.

Hayami, Ruttan. 1989. Agricultural Development An International Prespective. London: The John Hopkins Press.

Huda HM, Purnamadewi YL, Firdaus M. 2012. Strategi Pengembangan Perikanan dalam Pembangunan Ekonomi Wilayah Jawa Timur. Jurnal Ekuitas: Jurnal Ekonomi dan Keuangan. 18(3): 387-407.

Hastinawati I, Rum M. 2012. Keragaan Agroindustri Krupuk Udang di Desa Kwanyar Barat Kecamatan Kwanyar Kabupaten Bangkalan. Agriekonomika. 1(1): 15-24.

Ngamel KA. 2012. Analisis Finansial Usaha Budidaya Rumput Laut dan Nilai Tambah Tepung Karaginan di Kecamatan Kei Kecil, Kabupaten Maluku Tenggara. Jurnal Sains Terapan. 2(1): 68-83.

Lindawati. 2007. Faktor-Faktor yang Berpengaruh terhadap Peluang Berusaha dan Kegiatan Ekonomi Rumahtangga Istri Nelayan di Kecamatan Medan Belawan. Jurnal Perencanaan dan Pengembangan Wila-yah. 3(1): 1-8.

Oktaviani D, Sardjito. 2012. Pengembangan Industri Berbasis Perikanan dengan Pendekatan Pengembangan Ekonomi Lokal di Kabupaten Tuban. Jurnal Teknik POMITS. 1(1): 1 - 4.

Pertiwi KA, Affandi MI, Kasymir E. 2015. Nilai Tambah, Pengendalian Persediaan Ba- 
han Baku dan Pendapatan Usaha pada KUB Bina Sejahtera di Kelurahan Kangkung Kecamatan Bumi Waras Kota Bandar Lampung. Jurnal IImu-IImu Agribisnis. 3(1): 26-31.

Purwaningsih R. 2015. Analisis Nilai Tambah Produk Perikanan Lemuru di Pelabuhan Muncar Banyuwangi. Jurnal IImiah Teknik Industri. 14(1): 13-23.
Soejono D. 2008. Pola Pengembangan Agroindustri Berbasis Perikanan Laut di Puger Kabupaten Jember. Jurnal Sosial Ekonomi Pertanian. 2(1).

Zulkarnain, Lamusa A, Tangkesalu D. 2013. Analisis Nilai Tambah Kopi Jahe pada Industri Sal Han di Kota Palu. e-Journal Agrotekbis. 1(5): 493-499. 